\title{
PENERAPAN MODEL PROJECT BASED LEARNING PADA KOMPETENSI DASAR PELAKSANAAN PROSEDUR PENGELASAN DI SMK OTOMOTIF
}

\author{
Feta Mayo ${ }^{1}$, Wahid Munawar ${ }^{2}$, Ridwan A.M. Noor ${ }^{3}$ \\ Departemen Pendidikan Teknik Mesin \\ Universitas Pendidikan Indonesia \\ Jl. Dr. Setiabudhi No. 207 Bandung 40154 \\ fetamayo@ymail.com
}

\begin{abstract}
ABSTRAK
Tujuan penelitian ini adalah mendeskripsikan ketercapaian waktu pembelajaran pengelasan menggunakan model PJBL dan mendeskripsikan ketercapaian produk dalam pembelajaran pengelasan tersebut. Penerapan PJBL diharapkan dapat membekali peserta didik mengenai penerapan keterampilan pengelasan di dunia kerja secara menyeluruh, sehingga dapat berguna ketika terutama berwirausaha. Metode penelitian yang digunakan adalah metode pre-eksperimen dengan desain penelitian one shot case study dimana subjek penelitian diberikan treatment/perlakuan dan selanjutnya diobservasi hasilnya. Subjek pada penelitian ini terdiri dari 15 orang yang dibuat menjadi 5 grup. Grup terdiri dari peserta didik dengan nilai tinggi, rata-rata dan rendah. Teknik pengumpulan data menggunakan tes kinerja. Analisis data dilakukan pada waktu pengerjaan dan hasil produk. Hasil penelitian ini: (1) ketercapaian waktu pengerjaan produk selama 1080 menit waktu pembelajaran pengelasan, seluruh grup dapat menyelesaikan satu produk (meja praktik); (2) ketercapain produk oleh grup dengan nilai tertinggi dapat menyelesaikan tiga buah produk, yaitu meja praktik, rangka pot bunga, dan meja belajar. Grup nilai rata-rata menyelesaikan 3 buah produk yaitu meja praktik dan dua buah rangka pot bunga. Grup dengan nilai rendah menyelesaikan satu produk, yaitu meja praktik.
\end{abstract}

Kata Kunci: prosedur, produk, PJBL, kompetensi, pengelasan

\section{PENDAHULUAN}

Kompetensi keahlian yang harus dikuasai dalam jenjang pendidikan di SMK otomotif oleh peserta didik satu diantaranya adalah pelaksanaan prosedur pengelasan. Pembelajaran pengelasan bertujuan agar peserta didik memiliki keterampilan pengelasan (Yani. 2014). Keterampilan pengelasan dalam dunia kerja sangat diperlukan, baik di dunia industri maupun dunia usaha.

Pembelajaran prosedur pengelasan di SMK masih sering mengandalkan peran dominan dari guru. Sehingga menimbulkan pembelajaran yang pasif. Peserta didik hanya mengikuti apa yang diperintahkan oleh guru. Hasil pembelajaran pengelasan tidak menghasilkan apa-apa, padahal proses pembelajaran pengelasan membutuhkan bahan seperti besi dan elektroda. Bahan tersebut merupakan bahan habis pakai, sehingga perlu disediakan kembali setiap kali pembelajaran dan memerlukan biaya. Pembelajaran yang efektif dan efisien salah satunya ditentukan oleh penggunaan model pembelajaran yang tepat sasaran (Huda, 2014). Berdasarkan uraian masalah tersebut, salah satu alternatif

\footnotetext{
${ }^{1}$ Mahasiswa Departemen Pendidikan Teknik Mesin FPTK UPI

${ }^{2}$ Dosen Departemen Pendidikan Teknik Mesin FPTK UPI

${ }^{3}$ Dosen Departemen Pendidikan Teknik Mesin FPTK UPI
} 
model pembelajaran yang dapat diterapkan pada pembelajaran pengelasan adalah model project based learning. Project based learning (PJBL), yaitu pendekatan pembelajaran yang memperkenankan peserta didik untuk bekerja mandiri dalam mengkonstruksi pembelajarannya (pengetahuan dan keterampilan baru), dan mengkulminasinya dalam produk nyata (Abidin, 2014).

Penerapan model PJBL pada kompetensi dasar prosedur pengelasan berupaya untuk meningkatkan kualitas pembelajaran dengan maksud agar hasil belajar merupakan sebuah produk, sehingga penggunaan bahan praktik bisa menjadi benda yang dapat dimanfaatkan (Hanafiah dan Suhana, 2010). Tujuan penelitian penerapan model project based learning pada kompetensi dasar pelaksanaan prosedur pengelasan adalah untuk mengetahui ketercapaian waktu dan ketercapaian hasil dari pengerjaan produk selama pembelajaran pelaksanaan prosedur pengelasan. Pembelajaran berbasis proyek (project based learning) adalah model pembelajaran yang menggunakan proyek sebagai inti pembelajaran. Peran guru selama proses pembelajaran adalah sebagai fasilitator. Sintaks dalam proses pembelajaran project based learning adalah:

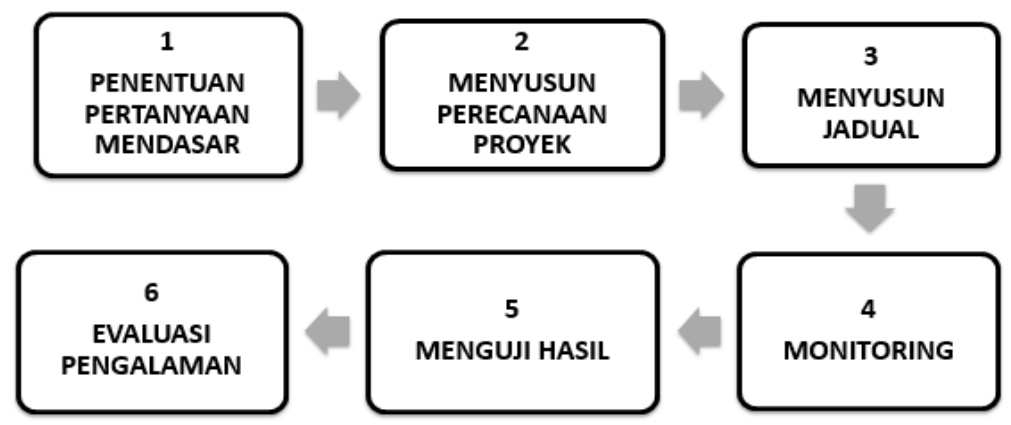

Gambar 1. Tahapan Pembelajaran Project Based Learning

Pembelajaran kompetensi dasar pengelasan menggunakan las busur listrik dengan elektroda terbungkus atau dikenal Shielded Metal Arc Welding (SMAW). Perlengkapan pengelasan terdiri dari: unit mesin las, perkakas tangan, keselamatan kerja dan elektroda. Beberapa prosedur yang harus diperhatikan selama pengelasan mulai dari penyalaan busur, langkah mengelas, penggerakan elektroda, bentuk sambungan dan posisi pengelasan (Suratman, 2001). Penerapan model project based learning pada kompetensi dasar pengelasan dengan proyek pengerjaan meja praktik dan rangka pot bunga. Proses pembelajaran dimulai dari:

1. Penentuan pertanyaan mendasar mengenai produk apa yang akan dibuat.

2. Menyusun perencanaan pengerjaan produk, mulai dari perencanaan desain produk, alat, bahan, dan langkah kerja. 

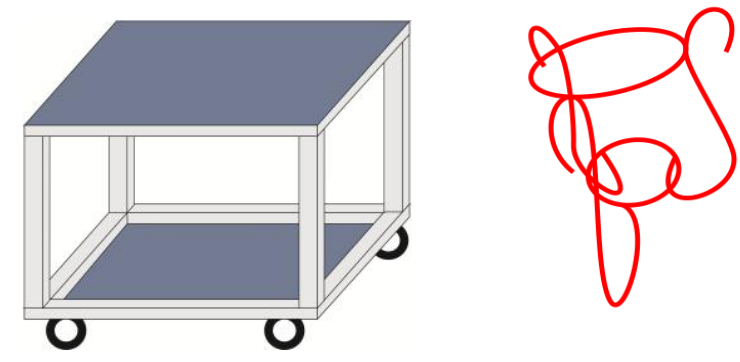

Gambar 2. Desain meja praktik dan rangka pot bunga

3. Menyusun jadwal pengerjaan produk

4. Monitoring guru terhadap peserta didik selama pengerjaan produk

5. Menguji hasil pengerjaan produk dan hasil akhir dari pengerjaan produk oleh guru. Pengerjaan produk dilihat dari aspek waktu pengerjaan dan persentase ketercapaian produk.

6. Evaluasi pengalaman selama proses pengerjaan produk dan hasil akhir dari pengerjaan produk.

\section{METODE PENELITIAN}

Metode penelitian yang digunakan dalam penelitian ini adalah metode eksperimen dengan bentuk pre-experimental yang menggunakan desain penelitian one shot case study. Penelitian dilaksanakan di SMK Al-Mufti Subang. Populasi dalam penelitian ini adalah seluruh peserta didik kelas X Teknik Sepeda Motor SMK Al-Mufti yang terdiri dari 109 orang. Teknik pengambilan sampel menggunakan sampling purposive dengan sampel yang diambil terdiri dari 15 orang peserta. Sampel dikelompokkan menjadi 5 grup berdasarkan kategori grup peserta didik dengan nilai tertinggi, nilai rata-rata, dan nilai terendah.

Prosedur penelitian meliputi tahap prelimenary, dilakukan analisis terhadap materi dan indikator pengelasan, serta sintak project based learning. Tahap kedua adalah self evaluation, pembuatan instrumen penelitian. Tahap berikutnya prototyping, instrumen diuji melalui expert judgment. Tahap terakhir adalah field test. Instrumen hasil pengujian digunakan di lapangan. Data yang didapat diolah dan dideskripsikan untuk membuat kesimpulan sebagai hasil penelitian.

Instrumen penelitian menggunakan jobsheet. Instrumen terdiri dari jobsheet pengerjaan meja praktik dan rangka pot bunga. Validitas instrumen dilakukan menggunakan validitas isi. Pengujian validitas isi yang dilakukan dengan expert judgment oleh dosen Departemen Pendidikan Teknik Mesin FPTK UPI, guru mata pelajaran 
pengelasan dan mekanik pengelasan. Analisa hasil tes kinerja dilakukan untuk mengetahui waktu rata-rata pengerjaan produk dan persentase ketercapaian pengerjaan produk.

\section{HASIL PENELITIAN}

Hasil penelitian yang telah diperoleh yaitu ketercapaian waktu pengerjaan produk meja praktik dan rangka pot bunga. Hasil rata-rata waktu pengerjaan meja praktik adalah 780 menit, sedangkan rata-rata waktu pengerjaan rangka pot bunga adalah 198 menit (Tabel 1). Ketercapaian hasil pengerjaan meja praktek dan rangka pot bunga sudah diperoleh (Tabel 2).

Tabel 2. Ketercapaian Waktu Pengerjaan Produk

\begin{tabular}{ccc}
\hline \multirow{2}{*}{ Kelompok } & \multicolumn{2}{c}{ Waktu Produk (menit) } \\
\cline { 2 - 3 } & Meja Praktik & Rangka Pot Bunga \\
\hline Grup 1 & 586 & 168 \\
Grup 2 & 690 & 195 \\
Grup 3 & 767 & 181 \\
Grup 4 & 899 & 201 \\
Grup 5 & 955 & 245 \\
\hline
\end{tabular}

Tabel 3. Ketercapaian Hasil Pengerjaan Produk

\begin{tabular}{ccc}
\hline \multirow{2}{*}{ Kelompok } & \multicolumn{2}{c}{ Hasil Produk (\%) } \\
\cline { 2 - 3 } & Meja Praktik & Rangka Pot Bunga \\
\hline Grup 1 & 91,77 & 89,79 \\
Grup 2 & 85,88 & 83,67 \\
Grup 3 & 89,41 & 89,79 \\
Grup 4 & 81,18 & 81,63 \\
Grup 5 & 78,82 & 79,59 \\
\hline
\end{tabular}

\section{PEMBAHASAN}

Berdasarkan dari hasil penelitian, grup dengan nilai tertinggi menyelesaikan meja praktik selama 586 menit dan rangka pot bunga selama 168 menit. Total waktu pengerjaan adalah 754 menit. Grup dengan nilai rata-rata menyelesaikan pengerjaan meja praktik selama 767 menit dan rangka pot bunga 181 menit. Total waktu pengerjaan adalah 948 menit. Grup dengan nilai terendah menyelesaikan pengerjaan meja praktik selama 955 menit dan rangka pot bunga selama 245 menit. Total waktu pengerjaan adalah 1200 menit. 
Alokasi waktu pembelajaran pengelasan berdasarkan silabus TSM SMK Al-mufti, diberikan selama 24 pertemuan dengan satu kali pertemuan adalah 45 menit. Total waktu pembelajaran yang disediakan dalam satuan menit adalah 24 x 45 menit $=1080$ menit. Kriteria ketuntasan minimal yang ditentukan oleh sekolah untuk pembelajaran pengelasan adalah 75, nilai ini setara dengan $75 \%$ dari persentase pencapaian pengerjaan proyek. Berdasarkan waktu pembelajaran pengelasan yang disediakan pada silabus, grup dengan nilai tertinggi dan nilai rata-rata dapat menyelesaikan dua produk selama pembelajaran pengelasan (Sanjaya, 2007). Grup dengan nilai terendah hanya dapat menyelesaikan satu produk saja, karena total waktu pengerjaan produk melebihi batas waktu yang disediakan.

Sisa waktu yang dimiliki oleh grup dengan nilai tertinggi dan nilai rata-rata dimanfaatkan untuk melakukan pengerjaan proyek lainnya, agar dapat memenuhi waktu pembelajaran pengelasan yang tersisa (Hosnan, 2014). Pengerjaan proyek berikutnya adalah grup dengan nilai tertinggi melakukan pengerjaan proyek meja belajar peserta didik, sedangkan grup dengan nilai rata-rata melakukan pengerjaan proyek rangka pot bunga dengan jenis banyak pot. Desain meja belajar dan rangka pot bunga dapat dilihat pada gambar berikut.

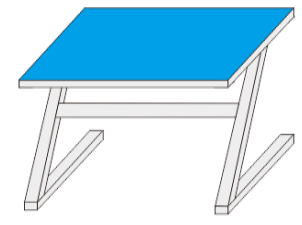

(a)

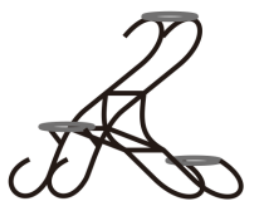

(b)

Gambar 3. Desain: (a) rangka pot bunga jenis banyak pot

(b) meja belajar peserta didik

Waktu yang dicapai oleh grup peserta didik untuk mengerjakan proyek meja praktik dengan nilai tertinggi adalah 586 menit dan peserta didik dengan nilai terendah adalah 955 menit. Rata-rata waktu pengerjaan meja praktik seluruh grup adalah 13 jam atau setara dengan 780 menit. Waktu yang dicapai oleh peserta didik dengan nilai tertinggi untuk pengerjaan rangka pot bunga adalah adalah 168 menit dan peserta didik dengan nilai terendah adalah 245 menit. Rata-rata waktu pengerjaan seluruh grup adalah 198 menit. Total waktu pengerjaan meja praktik dan rangka pot bunga, jika diambil rata-ratanya adalah 780 menit +198 menit $=978$ menit.

Pengerjaan meja praktik dan rangka pot bunga berdasarkan waktu rata-rata pengerjaan proyek dapat dilaksanakan selama pembelajaran pengelasan sesuai alokasi waktu yang disediakan yaitu selama 1080 menit, karena total rata-rata waktu pengerjaan 
proyek hanya 978 menit bahkan terdapat sisa waktu. Sisa waktu pembelajaran pengelasan adalah $1080-979=101$ menit

Grup peserta didik dengan nilai tertinggi (grup 1) selama proses pembelajaran pengelasan dapat menyelesaikan dua produk dengan total waktu pembelajaran selama 754 menit. Sisa waktu yang tersedia untuk mengerjakan produk berikutnya adalah $1080-754$ = 326 menit. Produk ketiga harus selesai maksimal selama 326 menit. Grup peserta didik dengan nilai rata-rata (grup 2 dan grup 3) selama proses pembelajaran pengelasan dapat menyelesaikan dua proyek dengan total waktu pembelajaran (ambil grup 3) selama 948 menit. Sisa waktu yang tersedia untuk mengerjakan produk berikutnya adalah $1080-948$ = 132 menit. Produk ketiga harus selesai maksimal selama 132 menit.

Grup peserta didik dengan nilai terendah (grup 4 dan grup 5) selama proses pembelajaran pengelasan dapat menyelesaikan dua proyek dengan total waktu pembelajaran (ambil grup 5) selama 1200 menit. Ketercapaian waktu pengerjaan proyek untuk grup tersebut melebihi batas waktu yang tersedia, yaitu $1080-1200=-121$ menit. Tanda negatif menandakan kelebihan waktu selama 121 menit. Berdasarkan data tersebut grup peserta didik dengan nilai terendah jika melihat dari waktu yang disediakan oleh silabus. Hanya dapat menyelesaikan pengerjaan meja praktik saja atau dapat dikatakan hanya dapat menyelesaikan satu produk saja.

Waktu yang digunakan oleh grup 1 dalam pengerjaan meja belajar peserta didik adalah selama 317 menit, sehingga total waktu yang digunakan oleh grup 1 untuk penyelesaian 3 produk adalah $754+317=1071$ menit. Berdasarkan catatan waktu tersebut, grup peserta didik dengan nilai tertinggi selama pembelajaran pengelasan dapat menyelesaikan 3 buah produk.

Waktu yang digunakan oleh grup 2 dan grup 3 dalam pengerjaan rangka pot bunga jenis banyak pot sekitar 144 hingga 148 menit (ambil 144 menit untuk grup 2), sehingga total waktu yang digunakan oleh grup 2 adalah $885+144=1029$ menit. Berdasarkan catatan waktu tersebut, grup peserta didik dengan nilai rata-rata selama pembelajaran pengelasan dapat menyelesaikan 3 buah produk (Tabel 3).

\begin{tabular}{|c|c|c|c|c|}
\hline \multicolumn{5}{|c|}{ Tabel 3.Total Waktu Pengerjaan Seluruh Grup } \\
\hline \multirow{2}{*}{ Grup } & \multicolumn{3}{|c|}{ Waktu Pengerjaan (menit) } & \multirow{2}{*}{$\begin{array}{l}\text { Total Waktu } \\
\text { (menit) }\end{array}$} \\
\hline & Produk 1 & Produk 2 & Produk 3 & \\
\hline 1 & 586 & 168 & 317 & 1071 \\
\hline 2 & 690 & 195 & 144 & 1029 \\
\hline 3 & 767 & 181 & 148 & 1096 \\
\hline 4 & 899 & 201 & - & 1100 \\
\hline 5 & 955 & 245 & ـ & 1200 \\
\hline
\end{tabular}


Ketercapaian hasil pengerjaan proyek oleh grup peserta didik dengan nilai tertinggi adalah $91,77 \%$ untuk pengerjaan meja praktik dan $89,79 \%$ untuk pengerjaan rangka pot bunga. Ketercapaian hasil pengerjaan proyek oleh grup peserta didik dengan nilai terendah adalah $78,82 \%$ untuk pengerjaan meja praktik dan 79,59\% untuk pengerjaan rangka pot bunga. Produk lanjutan yang dikerjakan oleh grup 1, yaitu pengerjaan meja belajar peserta didik memiliki ketercapaian produk sebesar 95,29\%. Produk lanjutan grup 2 dan grup 3 , yaitu pengerjaan rangka pot bunga jenis banyak pot memiliki persentase ketercapaian produk yang sama sebesar $89,66 \%$.

Berdasarkan standar kriteria ketuntasan minimal pembelajaran pengelasan yang telah ditentukan oleh silabus, semua grup dapat menyelesaikan proyek dengan hasil ketercapaian melebihi 75\%. Pembelajaran kompetensi dasar pelaksanaan prosedur pengelasan menggunakan model project based learning di SMK Al-Mufti jurusan Teknik Sepeda Motor dapat menghasilkan 2 hingga 3 macam proyek. Pengerjaan dari semua proyek ini dapat terselesaikan dengan baik dilihat dari hasil persentase pengerjaannya, namun waktu penyelesaian masing-masing grup berbeda-beda (Majid dan Firdaus, 2014).

\section{KESIMPULAN}

Penelitian dapat disimpulkan, yaitu ketercapaian waktu pengerjaan proyek selama 1080 menit dalam pembelajaran pengelasan oleh grup dengan nilai tertinggi yaitu untuk pengerjaan meja praktik selama 586 menit, rangka pot bunga selama 168 menit dan meja belajar peserta didik selama 317 menit dengan catatan total waktu yaitu 1071 menit. Grup dengan nilai terendah melakukan pengerjaan meja praktik dengan catatan waktu selama 955 menit. Waktu pengerjaan rangka pot bunga oleh grup dengan nilai terendah yaitu selama 245 menit, sehingga total waktu pengerjaan adalah 1200 menit. Total waktu pengerjaan oleh grup dengan nilai terendah melebihi batas waktu pembelajaran pengelasan. Ketercapaian hasil pengerjaan proyek selama pembelajaran pengelasan oleh grup dengan nilai tertinggi mencapai persentase $91,77 \%$ untuk meja praktik, $89,79 \%$ untuk rangka pot bunga dan 95,29\% untuk meja belajar peserta didik. Grup dengan nilai terendah mencapai persentase $78,82 \%$ untuk meja praktik dan $79,59 \%$ untuk rangka pot bunga.

\section{DAFTAR PUSTAKA}

Abidin, Y. (2014). Desain Sistem Pembelajaran dalam Konteks Kurikulum 2013. Bandung: Refika Aditama. 
Hanafiah, N. \& Suhana, C. (2010). Konsep Startegi Pembelajaran. Bandung: Refika Aditama.

Hosnan. (2014). Pendekatan Saintifik dan Kontekstual dalam Pembelajaran Abad 21. Jakarta: Ghalia Indonesia

Huda, M. (2014). Model-Model Pengajaran dan Pembelajaran. Yogyakarta: Pustaka Pelajar.

Majid, A. dan Firdaus, A. (2014). Penilaian Autentik Proses dan Hasil Belajar. Bandung: Interes Media.

Sanjaya, W. (2007). Strategi Pembelajaran Berorientasi Proses Pendidikan. Jakarta: Kencana Prenada Media Group.

Suratman, M. (2001). Teknik Mengelas Asetilin, Brazing, dan Las Busur Listrik. Bandung: Pustaka Grafika.

Yani. A. (2014). Mindset Kurikulum 2013. Bandung: Alfabeta. 